\title{
Sustainable energy education: addressing the needs of students and industry in Australia
}

\author{
Chris Lund ${ }^{1, *}$, Trevor Pryor $^{1}$, Philip Jennings ${ }^{1}$, Kim Blackmore ${ }^{2}$, Richard Corkish ${ }^{3}$, Wasim Saman ${ }^{4}$, Wendy Miller ${ }^{5}$, \\ Emiko Watanabe ${ }^{1}$, and Amanda Woods-McConney ${ }^{1}$ \\ ${ }^{1}$ School of Engineering and Information Technology, Murdoch University, Perth, Australia \\ 2 Australian National University, Canberra, Australia \\ ${ }^{3}$ University of New South Wales, Sydney, Australia \\ ${ }^{4}$ University of South Australia, Adelaide, Australia \\ ${ }^{5}$ Queensland University of Technology, Brisbane, Australia
}

Received: 16 January 2017 / Received in final form: 26 July 2017 / Accepted: 27 July 2017

\begin{abstract}
A survey has been carried out of graduates and employers working in the sustainable energy (SE) industry in Australia. The aims were to identify the key areas of content to be included in University level SE training and the type of degree structures that are most appropriate for SE professionals. Attention was also directed to the mode of instruction (online, blended or face-to-face) and the role of work-integrated learning (WIL). This paper presents the results of the survey, which provide guidance to Universities seeking to develop new, or revise existing, SE education offerings. The results of the survey clearly indicate that responding students and employers prefer a generalist degree in engineering, with a stream in sustainable energy as the initial qualification for professionals in this field. Specialist degrees at postgraduate level were also considered appropriate for continuing professional education (CPE). Both graduates and employers agreed on key areas to be included in the SE courses. These key areas are generic skills (research methods, team work, report writing), generation technologies (especially PV, wind and biomass), and enablers (such as economics, policy and project management). The graduates, many of whom came from overseas countries, generally agreed about the course content and its relevance to employment in their countries. Face-to-face or blended learning was preferred by both groups as the mode of instruction for the first degree. Online learning was considered a valuable adjunct in the undergraduate course and more suitable for CPE in postgraduate courses. WIL and more practical work were considered important, especially in the first degree. There was some disagreement about the appropriate length of work placements, with graduates preferring 6-8 weeks and employers 10-12 weeks. This work should provide a basis for further course development and curriculum reform for sustainable energy education.
\end{abstract}

\section{Introduction}

Education and training have a vital role to play in addressing climate change caused by anthropogenic greenhouse gas emissions [1,2]. Many nations are making substantial efforts to develop and implement mitigation and adaptation strategies and this work is producing a strong demand for professionals with an understanding of climate change and how to address it $[3,4]$. In response to this demand several Australian Universities introduced specialist tertiary level degree courses in the 1990s focused on sustainable energy (SE), renewable energy and energy management [5]. These courses have proven to be very popular with students and employers, but there has been

\footnotetext{
* e-mail: C.Lund@murdoch.edu.au
}

very little coordination of these offerings and no development of systematic sustainable energy curriculum frameworks.

This paper is based on a collaborative research project funded by the Australian Government's Office for Learning and Teaching [6], which involved key providers of courses in sustainable energy to the Australian community and to many international students who have travelled to Australia to study in this field. The aims of this project were to determine:

- What mix of inter/multi-disciplinary content and specialized content should be included in sustainable energy courses at undergraduate and postgraduate level? - Should universities offer specialist courses in sustainable energy at the undergraduate level or incorporate the relevant skills and knowledge into existing degree courses? 


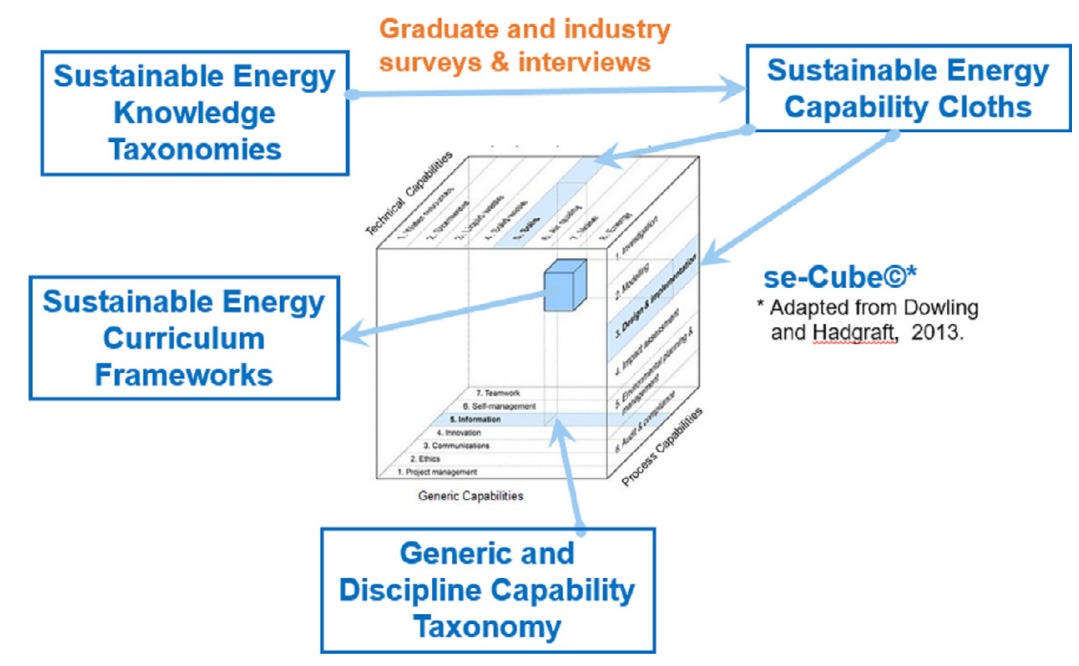

Fig. 1. Approach and methodology for developing the curriculum frameworks.

- Are specialist courses in sustainable energy needed at the postgraduate level for continuing professional education $(\mathrm{CPE})$ ?

- Is online delivery of these courses appropriate at the undergraduate and postgraduate levels?

- Is work-integrated learning (WIL) a useful component of courses in sustainable energy?

- How universal is the content of these courses, and do Australian courses in sustainable energy meet the needs of international students and Australian students who wish to work overseas?

This project was carried out during 2011-2014 and the detailed results are published in the final project report [6]. This paper is based on the graduate and industry surveys that were conducted in 2013 as a part of the process of developing the final curriculum frameworks.

\section{Methodology}

The first stage of this project involved the development of curriculum frameworks for sustainable energy education, based on a desktop study of what various universities in Australia and worldwide are offering their students and the validation of these with graduates and industry employers. A definition of sustainable energy was determined through a workshop process involving representatives from the five contributing Universities. The definition of sustainable energy used for the purposes of this study was:

"Sustainable energy is the provision of energy that meets the needs of the present without compromising the ability of future generations to meet their needs. Sustainable energy sources include all renewable energy sources, such as hydroelectricity, solar energy, wind energy, wave power, geothermal energy, bioenergy, and tidal power. It usually also includes technologies designed to improve energy efficiency."

The education considered was University level undergraduate and postgraduate coursework qualifications, essentially bachelor's degrees, graduate certificates or diplomas and Masters by coursework degrees. The disciplines included Engineering, Science, Policy and Business degrees separated into two categories, Engineering and Multidisciplinary. It did not include predominantly research degrees such as research Masters or PhDs. The expectation was that students undertaking these qualifications were looking to undertake careers in the sustainable energy industry either entering in the beginning of their careers (bachelors level) or transitioning from another field (postgraduate level). Therefore, the focus was on ensuring students have the relevant knowledge and skills required by industry when they graduate.

The topics were organized into knowledge sets under seven major headings [6]. In order to develop the final curriculum frameworks, the project adapted and extended the approach of Dowling and Hadgraft [7], developed for Environmental Engineering curriculums, and established curriculum mapping approaches (see for example - http:// uwf.edu/cutla/curriculum map graduate ALP.cfm).

The key elements of the approach to developing the final sustainable energy curriculum frameworks are summarized in Figure 1. The full details of the curriculum frameworks development process are given in Lund et al. [6].

A key element of the development of the curriculum frameworks were the generic and discipline capabilities (knowledge and skills) required by graduates which were determined by seeking input from graduates who are working in the sustainable energy industry and from employers of such graduates. The project also sought to gain an understanding of five key questions related to the delivery of sustainable energy skills and knowledge including: inter/multi-disciplinary training versus specialist courses (e.g. engineering, policy, etc.); specialist courses and programs versus embedding skills and knowledge into existing discipline training; face-to-face versus online and flexible delivery; the need for, and extent of, WIL based education that is optimal, or acceptable; and internationalisation of the curriculum so that it meets the needs of international students studying in Australia and Australian graduates seeking to work overseas. 
Table 1. Graduates' ratings of the importance of the main sustainable energy skills and knowledge areas.

\begin{tabular}{|c|c|c|c|c|c|c|}
\hline $\begin{array}{l}\text { Skill and knowledge } \\
\text { requirements - industry }\end{array}$ & $\begin{array}{l}\text { Degree } \\
\text { type }\end{array}$ & $N$ & $\begin{array}{l}\text { Not at all } \\
\text { important }\end{array}$ & $\begin{array}{l}\text { Somewhat } \\
\text { important }\end{array}$ & Important & $\begin{array}{l}\text { Very } \\
\text { important }\end{array}$ \\
\hline \multirow{4}{*}{ Power generation technologies } & Eng. & 31 & 2 & 5 & 13 & 11 \\
\hline & Multi. & 17 & 4 & 1 & 4 & 7 \\
\hline & All & 64 & 6 & 6 & 20 & 23 \\
\hline & Eng. & 31 & 0 & 1 & 9 & 20 \\
\hline \multirow[t]{3}{*}{ Generic skills and professional attributes } & Multi. & 17 & 1 & 0 & 5 & 10 \\
\hline & All & 64 & 1 & 2 & 18 & 33 \\
\hline & Eng. & 31 & 14 & 8 & 0 & 8 \\
\hline \multirow[t]{3}{*}{ Energy solutions for developing countries } & Multi. & 17 & 10 & 2 & 3 & 1 \\
\hline & All & 64 & 26 & 12 & 4 & 12 \\
\hline & Eng. & 31 & 10 & 14 & 4 & 2 \\
\hline \multirow{3}{*}{ Energy efficiency } & Multi. & 17 & 5 & 4 & 6 & 1 \\
\hline & All & 64 & 18 & 20 & 12 & 4 \\
\hline & Eng. & 31 & 3 & 7 & 3 & 18 \\
\hline \multirow{3}{*}{ Transmission, storage and network systems } & Multi. & 17 & 1 & 5 & 4 & 5 \\
\hline & All & 64 & 4 & 15 & 10 & 25 \\
\hline & Eng. & 31 & 4 & 8 & 11 & 7 \\
\hline \multirow{3}{*}{ Sustainable transport } & Multi. & 17 & 2 & 5 & 7 & 2 \\
\hline & All & 64 & 6 & 14 & 21 & 13 \\
\hline & Eng. & 31 & 4 & 4 & 13 & 10 \\
\hline \multirow{2}{*}{ Enablers (policy, economics, etc.) } & Multi. & 17 & 1 & 0 & 7 & 8 \\
\hline & All & 64 & 5 & 8 & 22 & 20 \\
\hline
\end{tabular}

\footnotetext{
* Degree type, where Eng. $=$ SE Engineering degree, Multi= Multidisciplinary (non-Engineering) SE degree, $N$ is the number of respondents to the questionnaire who indicated they hold each degree type. All is all respondents to the questionnaire, as some respondents did not categorise their degree. Not all respondents to the questionnaire provided answers to all questions.
}

Comprehensive questionnaires were developed by the project team, with professional assistance from Murdoch University's Teaching and Learning Centre. The questionnaires were distributed to the graduates of the member universities and to employers during the first half of 2013. The graduate respondents were identified by the research team members at each of the participating universities based on their graduates and alumni lists. The industry respondents were suggested by key industry associations and the knowledge of the research team. The industry associations sent out notification of the survey to their members and strongly encouraged them to participate. The distribution, responses and analysis were carried out online using Murdoch University's online survey system. In the final result 64 graduate responses were received and 27 responses from employers. This was considered to be sufficiently representative to give meaningful results.

\section{Results}

\subsection{Key areas of content}

The graduates expressed a strong interest in generic skills and professional attributes (e.g. project management, teamwork, research methods), generation technologies (such as PV, wind and biomass) and enablers (such as energy policy and economics). There was less interest in sustainable energy for sustainable development and energy efficiency. The lower level of interest in these two areas is likely to reflect the nature of the sustainable energy industry in Australia (e.g. a developed country) than being the case in other countries. These results are shown in Table 1.

The employers emphasized the need for generic skills and enablers, in agreement with the graduates and there was moderate support for generation technologies and energy efficiency. These responses are summarized in Table 2.

On the more detailed questions relating to the taxonomy there was strong graduate support for topics such as economics, environmental impacts, project management, energy efficiency, generation technologies, generic skills, networks, power quality, grid integration, smart grids, photovoltaics, solar thermal, wind power. The graduates supported the idea of having topics such as emerging generation technologies (e.g. waves, geothermal) and renewable energy and sustainable development available as electives. There was little interest in sustainable transport, which reflects the lack of emphasis in this area in Australia and may not be the case in other countries such as those in Europe.

In response to another question the graduates indicated that they believe that more is needed on grid operations, smart grids, networks, project management, business skills, regulatory frameworks, environmental law, standards, systems design, economics, auditing and building 
Table 2. Employer ratings of the importance of each of the main sustainable energy skills and knowledge areas.

\begin{tabular}{|c|c|c|c|c|c|c|}
\hline $\begin{array}{l}\text { Skill and knowledge } \\
\text { requirements - industry }\end{array}$ & $\begin{array}{l}\text { Degree } \\
\text { type }\end{array}$ & $N$ & $\begin{array}{l}\text { Not at all } \\
\text { important }\end{array}$ & $\begin{array}{l}\text { Somewhat } \\
\text { important }\end{array}$ & Important & $\begin{array}{l}\text { Very } \\
\text { important }\end{array}$ \\
\hline \multirow{3}{*}{ Power generation technologies } & Eng. & 9 & 1 & 1 & 3 & 4 \\
\hline & Multi. & 9 & 0 & 2 & 3 & 4 \\
\hline & All & 21 & 1 & 4 & 7 & 9 \\
\hline \multirow{3}{*}{ Generic skills and professional attributes } & Eng. & 9 & 0 & 1 & 5 & 3 \\
\hline & Multi. & 9 & 0 & 0 & 2 & 7 \\
\hline & All & 21 & 0 & 1 & 8 & 12 \\
\hline \multirow{3}{*}{ Energy solutions for developing countries } & Eng. & 9 & 5 & 3 & 1 & 0 \\
\hline & Multi. & 9 & 2 & 3 & 2 & 2 \\
\hline & All & 21 & 10 & 6 & 3 & 2 \\
\hline \multirow{4}{*}{ Energy efficiency } & Eng. & 9 & 2 & 2 & 3 & 2 \\
\hline & Multi. & 9 & 0 & 2 & 2 & 5 \\
\hline & All & 21 & 2 & 5 & 6 & 8 \\
\hline & Eng. & 9 & 3 & 1 & 1 & 4 \\
\hline \multirow[t]{3}{*}{ Transmission, storage and network systems } & Multi. & 9 & 0 & 6 & 1 & 2 \\
\hline & All & 21 & 3 & 8 & 3 & 7 \\
\hline & Eng. & 9 & 7 & 2 & 0 & 0 \\
\hline \multirow[t]{2}{*}{ Sustainable transport } & Multi. & 9 & 0 & 6 & 2 & 1 \\
\hline & All & 21 & 7 & 11 & 2 & 1 \\
\hline \multirow{3}{*}{ Enablers (policy, economics, etc.) } & Eng. & 9 & 2 & 1 & 3 & 3 \\
\hline & Multi. & 9 & 0 & 0 & 4 & 5 \\
\hline & All & 21 & 2 & 1 & 9 & 9 \\
\hline
\end{tabular}

services. They suggested that this extra material could be provided by removing discussion of obsolete technologies and software, reducing the emphasis on remote area power supplies and making topics like renewable energy and sustainable development and some emerging technologies into electives rather than mainstream units.

The industry respondents were in remarkable agreement with the graduates and differed only in one respect which was emphasizing the importance of testing and standards, in addition to all the other topics.

\subsection{General or specialist degree courses}

The SE graduates strongly supported the idea of a general Engineering degree with a stream in sustainable energy as the preferred form of undergraduate qualification in this field, as shown in Table 3. This is consistent with the preferences expressed for generic skills and the traditional engineering topics and enablers. Specialized undergraduate SE Engineering courses were also supported, but not as strongly. Non-engineering degrees (such as BSc) were not strongly supported at the undergraduate level, but there was stronger support at the postgraduate level (e.g. MSc in SE).

The responses from the employers were remarkably similar. They strongly preferred graduates with conventional engineering degrees with a SE stream or major included in them. A conventional postgraduate Engineering degree with a major in SE was deemed to be equally suitable, but there was less interest from employers in specialized SE degrees at either level.
These findings appear to confirm the current trend in many tertiary institutions in Australia where specialist undergraduate degrees are being phased out and replaced by modern generalist degrees with options for streams or specializations in major fields. It also appears that engineering is the preferred initial qualification for sustainable energy professionals, while specialized degrees in other areas may be more acceptable at the postgraduate level as CPE.

When asked to comment on whether a specialist undergraduate degree in SE or a generalist undergraduate degree followed by a specialist postgraduate degree would provide the best training both groups overwhelmingly supported the latter option. This is consistent with their responses to the previous questions about whether specialist or generalist undergraduate degrees were preferred for SE professionals. It is clear that the current market conditions favour those professionals who have a solid undergraduate qualification in a relevant branch of engineering, together with a specialization in $\mathrm{SE}$ or postgraduate qualifications in this field. The survey therefore has provided very clear guidance to universities on how to structure their SE offerings. This does not preclude graduates from fields other than engineering from entering the SE field, but it means that the market for their skills is much smaller.

It should be noted that while the majority of respondents favoured generalist Engineering degrees there are niche specialist Engineering degrees such as the UNSW Bachelor's and Master's degrees in Photovoltaics and Solar 
Table 3. Graduates' ratings of the ability of different types of University qualifications to prepare them for working in the sustainable energy industry.

\begin{tabular}{|c|c|c|c|c|c|c|}
\hline Degree types & Degree type & $N$ & $\begin{array}{l}\text { Not at all } \\
\text { relevant }\end{array}$ & Least able & Moderately able & Most able \\
\hline \multirow{4}{*}{$\begin{array}{l}\text { Specialized undergraduate } \\
\text { multidisciplinary } \\
\text { (non-Engineering) SE degree }\end{array}$} & Eng. & 31 & 3 & 17 & 6 & 4 \\
\hline & Multi. & 17 & 0 & 8 & 7 & 2 \\
\hline & All & 64 & 3 & 28 & 13 & 7 \\
\hline & Eng. & 31 & 1 & 3 & 11 & 15 \\
\hline \multirow{2}{*}{$\begin{array}{l}\text { Specialized undergraduate } \\
\text { SE Engineering degree }\end{array}$} & Multi. & 17 & 0 & 4 & 6 & 6 \\
\hline & All & 64 & 1 & 7 & 21 & 21 \\
\hline \multirow{3}{*}{$\begin{array}{l}\text { Conventional undergraduate } \\
\text { degree (e.g. Science) } \\
\text { with major in SE }\end{array}$} & Eng. & 31 & 1 & 14 & 9 & 5 \\
\hline & Multi. & 17 & 0 & 7 & 8 & 2 \\
\hline & All & 64 & 1 & 21 & 19 & 8 \\
\hline \multirow{4}{*}{$\begin{array}{l}\text { Conventional undergraduate } \\
\text { Engineering degree } \\
\text { with major/stream in SE }\end{array}$} & Eng. & 31 & 0 & 4 & 10 & 16 \\
\hline & Multi. & 17 & 0 & 1 & 13 & 2 \\
\hline & All & 64 & 0 & 5 & 26 & 19 \\
\hline & Eng. & 31 & 2 & 6 & 13 & 9 \\
\hline \multirow{3}{*}{$\begin{array}{l}\text { Specialized postgraduate } \\
\text { multidisciplinary SE degree }\end{array}$} & Multi. & 17 & 0 & 2 & 8 & 6 \\
\hline & All & 64 & 2 & 8 & 24 & 16 \\
\hline & Eng. & 31 & 1 & 1 & 10 & 18 \\
\hline \multirow{2}{*}{$\begin{array}{l}\text { Specialized postgraduate SE } \\
\text { Engineering degree }\end{array}$} & Multi. & 17 & 0 & 1 & 8 & 7 \\
\hline & All & 64 & 1 & 3 & 18 & 28 \\
\hline \multirow{3}{*}{$\begin{array}{l}\text { Conventional postgraduate } \\
\text { non-Engineering degree } \\
\text { with major in SE }\end{array}$} & Eng. & 31 & 3 & 13 & 8 & 6 \\
\hline & Multi. & 17 & 1 & 6 & 6 & 3 \\
\hline & All & 64 & 4 & 19 & 17 & 10 \\
\hline \multirow{3}{*}{$\begin{array}{l}\text { Conventional postgraduate } \\
\text { Engineering degree with } \\
\text { major in SE }\end{array}$} & Eng. & 31 & 1 & 2 & 13 & 12 \\
\hline & Multi. & 17 & 0 & 5 & 9 & 2 \\
\hline & All & 64 & 1 & 8 & 23 & 16 \\
\hline
\end{tabular}

* Responders were asked to rank (relative to each other) what they felt (based on their experience) was the ability of different types of University qualifications to prepare them for working in the sustainable energy industry. "Least able" meant they felt the degree had the least ability to prepare them whilst "Most able" meant they felt it had the most ability.

Energy Engineering degrees which meet a niche demand for photovoltaics manufacturing. The relatively small number of graduates from this program (relative to those from general SE Engineering degrees) are in high demand. Employers in this specialized area require graduates to have a more specialized training.

\subsection{Online or face-to-face learning}

Several universities are now offering online studies in SE at undergraduate and postgraduate levels [8-10]. In response to a question regarding the preferred delivery option, both groups expressed a definite preference for conventional classroom learning or blended learning (a mixture of faceto-face and online) over purely online learning. There was very little difference in the support for classroom and blended learning in both groups of respondents. The results for the graduates are presented in Table 4.

Many of the respondents provided reasons for their answers, including: SE needs hands on training and interaction with industry professionals; internships and field trips are an important part of SE training; face-to-face learning is very important for undergraduates; group work is also an important skill that undergraduates should learn. Some respondents said that blended learning was a valuable adjunct to classroom learning as it provided further support for their studies and it provided flexibility for those who could not always attend classes. Many considered that online learning was more suited to advanced undergraduate and postgraduate studies once the basics had been developed in the classroom and through work experience.

\subsection{Work-integrated learning}

Another set of questions in the survey related to skills development and the best ways to achieve this. Both groups of respondents replied in a similar way by saying that more practical work and job training than currently provided would be useful. More opportunity for field trips and networking opportunities were also suggested. A set of specific questions were asked about WIL, which is an important part of many undergraduate Engineering degrees. The graduates rated WIL strongly for undergrad- 
Table 4. Graduates ratings of the desirability of the currently available delivery options for tertiary level SE courses.

\begin{tabular}{llllrrr}
\hline Delivery options & $\begin{array}{l}\text { Degree } \\
\text { type }\end{array}$ & $N$ & $\begin{array}{l}\text { Least } \\
\text { desirable }\end{array}$ & Desirable & $\begin{array}{l}\text { Highly } \\
\text { desirable }\end{array}$ & $\begin{array}{l}\text { Unable to } \\
\text { comment }\end{array}$ \\
\hline \multirow{2}{*}{ Conventional campus based } & Eng. & 31 & 1 & 9 & 20 & 0 \\
face-to-face learning only & Multi. & 17 & 1 & 7 & 7 & 2 \\
& All & 64 & 2 & 18 & 29 & 2 \\
Online/flexible delivery only & Eng. & 31 & 15 & 5 & 5 & 5 \\
based learning & Multi. & 17 & 2 & 6 & 7 & 2 \\
Blended learning (mixture of face-to-face & All & 64 & 18 & 13 & 13 & 7 \\
and online/flexible delivery) & Multi. & 31 & 1 & 11 & 15 & 2 \\
& All & 64 & 0 & 5 & 11 & 1 \\
\hline
\end{tabular}

uate degrees and less strongly for postgraduate degrees. In contrast, the employers rated WIL much more strongly and suggested it was vital for both undergraduate and postgraduate degrees.

When asked about the optimal length of WIL, the graduates showed a preference for $6-8$ weeks, while the employers preferred 10-12 weeks. The difference is probably explained by the fact that many undergraduates have multiple commitments to work and family as well as to their studies and they would prefer the minimum period of WIL as it tends to fully occupy their time and displace other activities. The employers however were probably thinking that short placements have little value as the students need at least 3 months in the workplace to do a significant piece of work. Clearly there is difference here that needs to be investigated further and resolved. When asked about the amount of WIL in their training the majority of graduates said that there was not enough. Clearly this needs to be addressed by course designers.

Both groups were asked to rate the importance of industry practitioners having direct involvement in teaching. The industry respondents rated it very highly while the graduates also supported it, but not quite as strongly. The employers said that industry involvement helped to keep courses up to date and relevant and they recommended that industry provide guest lecturers and supervisors for student projects. While the graduates also supported industry involvement, some of them noted that industry staff are generally not trained educators and some of their presentations were disappointing. The graduates were divided about whether there was already enough industry participation in university teaching. This issue needs to be handled carefully to ensure that high standards of education are maintained with substantial industry input into teaching and course design.

\subsection{International relevance of Australian university sustainable energy training}

Both groups were asked whether the current courses in the Australian universities the graduates attended provided skills and knowledge that were internationally relevant. The majority of graduates thought that their training was internationally relevant and would prepare them to work in SE anywhere in the world. It appears that the current course content in Australian University courses is sufficiently international to provide a good basis for employment outside Australia. Most Australian universities are acutely aware of this issue because of the large proportion of overseas students who come to Australia to study engineering.

While the results are based on the perceptions of the surveyed graduates and are not based on collected evidence that the graduates have found employment in these areas overseas they are pertinent. Although only graduates of Australian Universities were questioned in the study many of these Australian graduates have international experience or have come from overseas.

\section{Conclusions}

This study of graduates and employers in the sustainable energy industry has provided useful information for sustainable energy curriculum designers and teachers at University level. It clearly indicates that the responding students and employers prefer a generalist undergraduate degree in engineering, with a stream in sustainable energy as the initial qualification for professionals in this field. Specialist degrees at postgraduate level are also appropriate for CPE. The graduates and employers agree on the key areas to be included in the SE courses and this information will be valuable for curriculum and course designers throughout the world. The graduates, many of whom come from overseas countries, generally agreed about the course content and its relevance to employment in their countries.

Face-to-face or blended learning is preferred by both groups as the mode of instruction for the first degree. Online learning is considered to be a valuable adjunct in the undergraduate course and more suitable for continuous professional education in postgraduate courses. WIL and more practical work are considered to be important, especially in the first degree. There is some disagreement about the appropriate length of work placements. The results of this work should provide a basis for further course development and curriculum reform. 
The research in this paper was funded by the Australian Government Office for Learning and Teaching. The authors wish to acknowledge all of the sustainable energy graduates and employers who completed the questionnaire.

\section{References}

1. P.J. Jennings, C.P. Lund, Renew. Energy 22, 113 (2001)

2. P.J. Jennings, Renew. Energy 34, 435 (2009)

3. P.J. Jennings, O.P. Dubey, C.P. Lund, in Proceedings of the International Solar Energy Congress, ISES 2001, Adelaide, 2001

4. M. Taleghani, H.R. Ansar, P. Jennings, Energy Educ. Sci. Technol. 2, 111 (2010)
5. C. Thomas, P. Jennings, B. Lloyd, Solar Progress (2008)

6. C. Lund, P. Jennings, T. Pryor, K. Blackmore, R. Corkish, W. Saman, W. Miller, A. Woods-McConney, E. Watanabe, Office for Learning and Teaching Final Report, 2014, ISBN: 978-1-74361-891-2, available from: http://www.olt.gov.au/ project-renewing-sustainable-energy-curriculum-21st-centu ry-providing-internationally-relevant-ski-0

7. D. Dowling, R. Hadgraft, A Graduate Capability Framework for Environmental Engineering Degree Programs. A Guide for Australian Universities, Office of Teaching and Learning, 2013, ISBN: 978-1922125-92-7

8. C.P. Lund, P.J. Jennings, Renew. Energy 22, 119 (2001)

9. K.L. O'Mara, P.J. Jennings, Renew. Energy 22, 135 (2001)

10. C. Thomas, P. Jennings, B. Lloyd, Aust. J. Environ. Educ. 24, 67 (2008)

Cite this article as: Chris Lund, Trevor Pryor, Philip Jennings, Kim Blackmore, Richard Corkish, Wasim Saman, Wendy Miller, Emiko Watanabe, Amanda Woods-McConney, Sustainable energy education: addressing the needs of students and industry in Australia, Renew. Energy Environ. Sustain. 2, 40 (2017) 